\title{
Factors at medical school influencing students' decisions to pursue a career in ophthalmology
}

\author{
Andrew M. Hsiao' ${ }^{1}$ Andrew J. Tatham ${ }^{2}$
}

Received: 9 November 2017 / Accepted: 17 November 2017 / Published online: 5 February 2018

(c) The Royal College of Ophthalmologists 2018

Ophthalmology is an attractive speciality, with a high competition ratio for entry to training. Recently, in the United Kingdom, the ratio of applicants to places in ophthalmology speciality training (residency) has ranged from 3.1:1 (2012) to 4.8:1 (2016) compared to 1.3:1 for general practice (2016) [1, 2]. Despite its popularity, limited exposure during medical school may deter some from considering ophthalmology as a career. Students from different medical schools have been found to have different career preferences, perhaps due to variation in medical school curricula, teaching style, or support from specialist student societies, for example, an ophthalmology society [3].

Although differences between medical schools may influence choice of speciality, to the best of our knowledge the relationship between exposure to ophthalmology at medical school and likelihood of choosing ophthalmology as a career has not been examined. We conducted a survey of UK medical schools to attempt to answer this question. Between February 2017 and May 2017, all 32 eligible UK medical schools were contacted by e-mail requesting data on the length of compulsory clinical ophthalmology teaching in the curriculum. Medical schools that failed to respond were emailed a reminder and then telephoned if they had still not responded. We also enquired as to whether universities had an official ophthalmology student society, with roles of such societies including hosting guest lectures, facilitating research or audit projects, and arranging conferences and extracurricular educational events.

Our primary outcome was an estimate of the percentage of final year students from each university entering

Andrew J. Tatham

andrewjtatham@gmail.com or andrewhsiao94@gmail.com

1 College of Medicine and Veterinary Medicine, University of Edinburgh, Edinburgh, UK

2 Princess Alexandra Eye Pavilion and Department of Ophthalmology, University of Edinburgh, Edinburgh, UK ophthalmology specialist training following foundation years (internship). This was derived from information regarding the alma mater of current ophthalmology specialist trainees (ST1 to ST7) obtained from the Royal College of Ophthalmologists and the number of students in each medical school obtained from The Medical School Application Guide [4]. As a further indicator of interest in ophthalmology, we also collected data on the number of students from each university sitting the Royal College of Ophthalmologist undergraduate examination (Duke-Elder examination).

\section{Results}

Twenty-five of 32 (78\%) medical schools provided information regarding the length of ophthalmology undergraduate teaching. Eighteen $(72 \%)$ had compulsory ophthalmology teaching of 1 week or less and six (24\%) had teaching for more than 1 week (Table 1). There was a wide range in the proportion of students from each medical school entering ophthalmology training, ranging from none to almost $2 \%$, with an average $( \pm$ SD) of $0.69 \pm 0.53 \%$. There was no significant relationship between the percentage of students in ophthalmology training and the duration of undergraduate ophthalmology teaching $\left(R^{2}=0.019, P=0.519\right)$. Eighteen of 32 universities (56.3\%) had an ophthalmology society and those with a society had a significantly higher proportion of students entering ophthalmology training than those without $(0.87 \pm 0.48 \%$ versus $0.46 \pm 0.52 \%, P=0.004)$. The presence of an ophthalmology society was associated with a 1.37-fold increase in percentage of students training in ophthalmology $(P=0.030)$. On average, $6.19 \pm 3.92 \%$ of students from each medical school sat the Duke-Elder examination. There was no significant relationship between the proportion of students sitting the Duke-Elder examination and the proportion of alumni in ophthalmology training $\left(R^{2}=0.009, P=0.616\right)$. Multivariable regression analysis, including duration of ophthalmology teaching and the percentage of students from each university sitting the Duke-Elder, showed the presence of an 
Table 1 Overview of data received organized by each eligible medical school

\begin{tabular}{|c|c|c|c|c|}
\hline Medical school & $\begin{array}{l}\text { Length of } \\
\text { clinical rotation }\end{array}$ & $\begin{array}{l}\text { Ophthalmology } \\
\text { society }\end{array}$ & $\begin{array}{l}\% \text { of students } \\
\text { sitting Duke- } \\
\text { Elder }\end{array}$ & $\begin{array}{l}\% \text { of students } \\
\text { commencing } \\
\text { ophthalmology training }\end{array}$ \\
\hline Aberdeen & 1 week & Yes & 4.34 & 0.54 \\
\hline $\begin{array}{l}\text { Barts (Queen Mary } \\
\text { London) }\end{array}$ & 1 week & Yes & 6.51 & 0.73 \\
\hline Birmingham & 2 weeks & Yes & 4.20 & 0.39 \\
\hline $\begin{array}{l}\text { Brighton and } \\
\text { Sussex }\end{array}$ & 7.5 days & Yes & 6.43 & 0.41 \\
\hline Bristol & 1 week & Yes & 6.77 & 0.80 \\
\hline Cambridge & 1 week & Yes & 1.99 & 0.90 \\
\hline Cardiff & 1 week & Yes & 1.71 & 0.16 \\
\hline Dundee & 1.5 weeks & Yes & 18.06 & 1.59 \\
\hline Edinburgh & 1 week & Yes & 12.08 & 1.31 \\
\hline Exeter & 1 week & No & 2.50 & 0.12 \\
\hline Glasgow & 1 week & Yes & 4.44 & 0.40 \\
\hline Hull-York & No response & No & 5.71 & 0.21 \\
\hline Imperial College & 1 week & Yes & 3.31 & 1.47 \\
\hline Keele & No response & No & 1.44 & 0.21 \\
\hline Kings & No response & No & 11.24 & 0.63 \\
\hline Lancaster & $\begin{array}{l}\text { Less than a } \\
\text { week }\end{array}$ & No & 11.11 & 0.00 \\
\hline Leeds & 1 week & No & 4.93 & 1.22 \\
\hline Leicester & 2 weeks & Yes & 1.61 & 0.75 \\
\hline Liverpool & No response & Yes & 7.14 & 0.63 \\
\hline Manchester & 1 week & Yes & 1.53 & 0.87 \\
\hline Newcastle & Variable & Yes & 6.41 & 0.54 \\
\hline $\begin{array}{l}\text { Norwich (East } \\
\text { Anglia) }\end{array}$ & 2 weeks & No & 13.17 & 0.26 \\
\hline Nottingham & 2 weeks & No & 5.20 & 0.48 \\
\hline Oxford & 2 weeks & Yes & 3.74 & 1.68 \\
\hline $\begin{array}{l}\text { Plymouth } \\
\text { (Peninsula) }\end{array}$ & 1 week & Yes & 7.61 & 0.77 \\
\hline Queen's Belfast & 1 week & No & 7.25 & 0.38 \\
\hline Sheffield & No response & No & 1.16 & 0.44 \\
\hline Southampton & 1 week & No & 7.44 & 0.36 \\
\hline St George's & 1 week & Yes & 5.00 & 1.65 \\
\hline Swansea & No response & No & 11.11 & 0.00 \\
\hline $\begin{array}{l}\text { University College } \\
\text { London }\end{array}$ & 1 week & No & 6.98 & 1.93 \\
\hline Warwick & No response & No & 6.10 & 0.26 \\
\hline
\end{tabular}

ophthalmology society remained significantly associated with a greater percentage of students entering ophthalmology training (1.38-fold increase, 95\% confidence interval (CI): 1.05-1.71, $\left.R^{2}=0.179, P=0.025\right)$.

\section{Discussion}

The results of this survey suggest that longer duration of compulsory undergraduate ophthalmology teaching is not related to an increased proportion of students entering ophthalmology training. However, it is important to acknowledge that duration of ophthalmology teaching was short in all medical schools, in none longer than 2 weeks and longer duration of teaching may have had an impact. Duration of teaching may be less important than quality of teaching and student engagement, which we attempted measure. Although there was no relationship between proportion of students sitting the Duke-Elder examination and proportion entering ophthalmology training, medical 
schools with an ophthalmology student society were better represented among current ophthalmology trainees. Although the relationship may not be causal, it suggests that students attending a medical school with an ophthalmology society may have a higher chance of securing an ophthalmology training position.

We were surprised to find no association between higher rates of Duke-Elder participation and higher rates of ophthalmology trainees; however, others have recently highlighted that there may be a perceived relative "unimportance" of the Duke-Elder examination during ophthalmology trainee shortlisting due to the scoring system used for shortlisting [5, 6]. The points awarded for a good Duke-Elder score can be obtained elsewhere through publications, presentations, and research experience. As suggested by Joshi et al. [5], this insignificant weighting in the shortlist criteria may dissuade potential candidates from participating in the Duke-Elder examination.

Other studies have shown that exposure to specialties during clerkship years appears to be a vital influence of career preference [7-10]. Our survey was limited in observing length and not quality of teaching. A further limitation was that although we had a $78 \%$ response rate, we were unable to obtain information about teaching for all universities, which may have reduced our ability to detect a relationship. Furthermore, we examined the proportion of students entering ophthalmology training, not the proportion applying or rate of successful applications, which would be interesting the evaluate. However, despite limitations, this study suggest university societies may have importance for encouraging students to seek a career in ophthalmology and successfully apply to an ophthalmology training programme.

Funding This work was supported in part by NHS Research Scotland Career Research Fellowship Grant (AJT).

\section{Compliance with ethical standards}

Conflict of interest Dr. Tatham reported receiving Research support from Heidelberg Engineering. The remaining author declares that they have no competing interests.

\section{References}

1. Kennedy C. Specialty training applications for entry in 2016: competition ratios and the application process. BMJ Careers; 2015. http://careers.bmj.com/careers/advice/Specialty_training_a pplications_for_entry_in_2016\%3A_competition_ratios_and_ the_application_process. Accessed 3 May 2017.

2. 2016-CT1/ST1 Competition Ratios. 2016. https://specialtytra ining.hee.nhs.uk/Portals/1/Competition\%20Ratios\%202016\% 20ST1_1.pdf. Accessed 3 May 2017.

3. Cleland JA, Johnston PW, Anthony M, Khan N, Scott NW. A survey of factors influencing career preference in new-entrant and exiting medical students from four UK medical schools. BMC Med Educ. 2014;14:151.

4. Competition Ratios-UK medical schools. http://www.themsag. com/uk-medical-schools/competition-ratios. Accessed 3 May 2017.

5. Joshi L, Shanmuganathan VA, Kneebone RL, Amoaku W. Performance in the Duke-Elder ophthalmology undergraduate prize examination and future careers in ophthalmology. Eye (Lond). 2011;25:1027-33.

6. London Deanery. ST1 Ophtahlmology Example Shortlist Scoresheet. 2011. http://www.londondeanery.ac.uk/var/recruitment/ specialtyrecruitment/files/2011/shortlist-scoreshets/gti-2011shortlistscoresheetophthalmology-st1-v3.pdf/download.

7. Makama JG, Ameh EA. Does general surgery clerkship make a future career in surgery more appealing to medical students? Afr Health Sci. 2010;10:292-6.

8. Singh N, Causey W, Brounts L, Clouse WD, Curry T, Andersen $\mathrm{C}$, et al. Vascular surgery knowledge and exposure obtained during medical school and the potential impact on career decisions. J Vasc Surg. 2010;51:252-8.

9. Goltz CJ, Bachusz RC, Mancini E, Rits Y, Mattos MA, Rubin JR. Medical student career survey-vascular surgery awareness initiative. Ann Vasc Surg. 2013;27:225-31.

10. Pianosi K, Bethune C, Hurley KF. Medical student career choice: a qualitative study of fourth-year medical students at Memorial University, Newfoundland. Can Med Assoc. 2016;4:147-52. 